\title{
GAMBARAN KERUSAKAN GIGI PENYANGGA PADA PENGGUNA GIGI TIRUAN SEBAGAI LEPASAN DI KELURAHAN BATU KOTA
}

\author{
${ }^{1}$ Cicilia A. Fernatubun \\ ${ }^{2}$ Damajanty H. C. Pangemanan \\ ${ }^{3}$ Vonny N. S. Wowor
}

\author{
${ }^{1}$ Kandidat Skripsi Program Studi Pendidikan Dokter Gigi Fakultas Kedokteran \\ ${ }^{2}$ Bagian Fisiologi Fakultas Kedokteran \\ ${ }^{3}$ Program Studi Pendidikan Dokter Gigi Fakultas Kedokteran \\ Universitas Sam Ratulangi Manado \\ E-mail: ciciliafernatubun58gmail.com
}

\begin{abstract}
Removable partial denture is inserted in the mouth after remained generally require maintenance. Most people who think that the problem of missing teeth in the oral cavity has been overcome with the use of dentures, but in fact the use of denture without maintenance of good oral health can lead to disrupted. Oral hygiene that is not maintained properly can result in an increase in plaque and caries and periodontal disease more. The aim of this study was to assess the damage abutment on the user partial dentures in Kota Batu village. This study is a descriptive study with cross sectional study. The sampling technique used purposive sampling with a sample size in this study of 81 patients. The data were collected with intra oral examinatio. The results of this study indicate damage to the gear elements that serve as a buffer in the form of caries and fractures by 59 damage and damage to the tissues supporting the teeth in the form of mobility of teeth, gingivitis, bleeding and periodontitis by 72 damage. In this study found the majority of respondents suffered damages in abutment with the most damage occurred on the elements of the teeth that serve as the backbone is in the form of caries damage and damage most of the tissues supporting the abutment is damage in the form of gingivitis.
\end{abstract}

Keywords: removable partial dentures, tooth decay buffer

\begin{abstract}
Abstrak: Gigi Tiruan Sebagian Lepasan setelah dipasang dalam mulut pada umumnya tetap memerlukan pemeliharaan. Kebanyakan individu yang kehilangan gigi berpikir bahwa masalah pada rongga mulut sudah teratasi dengan pemakaian gigi tiruan, namun kenyataannya penggunaan gigi tiruan tanpa pemeliharaan yang baik dapat mengakibatkan kesehatan rongga mulut terganggu. Kebersihan mulut yang tidak dijaga dengan baik dapat mengakibatkan meningkatnya plak dan terjadi peningkatan karies dan penyakit periodontal lainnya. Tujuan dari penelitian ini untuk mengetahui gambaran kerusakan gigi penyangga pada pengguna Gigi Tiruan Sebagian Lepasan di Kelurahan Batu Kota. Penelitian ini merupakan penelian deskriptif dengan pendekatan cross sectional study. Teknik pengambilan sampel yang menggunakan purposive sampling dengan jumlah sampel dalam penelitian ini sebanyak 81 orang. Pengambilan data dilakukan dengan pemeriksaan intra oral. Hasil penelitian ini menunjukkan kerusakan pada elemen gigi yang dijadikan sebagai penyangga berupa karies dan fraktur sebesar 59 kerusakan dan kerusakan pada jaringan pendukung gigi berupa mobilitas gigi, gingivitis, perdarahan dan periodontitis sebesar 72 kerusakan. Pada penelitian ini ditemukan sebagian besar responden mengalami kerusakan pada gigi penyangga kerusakan yang paling banyak terjadi pada elemen gigi geligi yang dijadikan sebagai penyangga ialah kerusakan berupa karies dan kerusakan terbanyak pada jaringan penunjang gigi penyangga ialah kerusakan berupa gingivitis.
\end{abstract}

Kata kunci: gigi tiruan sebagian lepasan, kerusakan gigi penyangga 
Gigi memiliki peran yang sangat penting bagi manusia, tanpa gigi beberapa fungsi dapat mengalami gangguan. Fungsi gigi berupa fungsi fonetik, mastikasi dan estetik. Tanggalnya gigi dapat mengakibatkan kemampuan menelan dan mencerna makanan berkurang, namun gangguan yang terjadi bukan hanya pada proses pengunyahan tetapi juga terhadap kemampuan seseorang dalam mengucapkan beberapa huruf dengan baik. Gangguan yang terjadi akibat kehilangan gigi bisa dicegah dengan pembuatan gigi tiruan untuk menggantikan gigi yang hilang. ${ }^{1}$

Menurut hasil Riset Kesehatan Dasar 2007, prevalensi penggunaan gigi tiruan untuk menggantikan gigi yang hilang di Indonesia sebesar 4,6\% dan prevalensi penggunaan gigi tiruan di Sulawesi Utara sebesar $7,1 \%{ }^{2}$

Pada kasus kehilangan beberapa gigi baik gigi pada rahang atas maupun rahang bawah dapat menggunakan gigi tiruan sebagian lepasan (GTSL). Pada pemakai GTSL, gigi penyangga menghadapi resiko terjadinya kerusakan, kerusakan pada gigi penyangga dapat berupa kerusakan pada elemen gigi penyangga dan kerusakan pada jaringan penunjang disekitar gigi penyangga. ${ }^{3}$

Elemen gigi penyangga adalah gigi asli yang dijadikan tempat sandaran cengkram ataupun konektor pada GTSL berbasis akrilik maupun GTSL kerangka logam. Sebagai penyangga atau sandaran ccengkeram, gigi merupakan satu kesatuan dengan jaringan penunjangnya, sehingga dalam pemilihan gigi geligi sebagai penyangga harus diperhatikan kondisi gigi geligi itu sendiri serta kondisi jaringan penunjangnya. Kondisi gigi geligi yang dijadikan sebagai gigi penyangga harusnya sehat dan cukup kuat, akarnya panjang, kedudukan gigi hendaknya tegak lurus dengan prsesus alveolaris, dan tidak mengalami penyakit periodontal. ${ }^{3,4}$

Kerusakan pada gigi penyangga dibedakan menjadi dua yaitu kerusakan pada elemen gigi asli yang dijadikan penyangga dan kerusakan pada jaringan pendukung gigi itu sendiri. Kerusakan pada gigi berupa karies dan fraktur dan kerusakan pada jaringan penunjang gigi yang berupa gingivitis, periodontitis, perdarahan dan mobilitas. ${ }^{5,6,7,8}$

\section{BAHAN DAN METODE PENELITIAN}

Jenis penelitian yang digunakan yaitu deskriptif dengan menggunakan pendekatan cross-sectional study, dengan melakukan pengukuran dalam satu waktu. Penelitian ini dilaksanakan di Kelurahan Batu Kota pada bulan Februari - November 2014.

Populasi penelitian ini adalah masyarakat Kelurahan Batu Kota yang menggunakan gigi tiruan sebagian lepasan yaitu sebanyak 355 orang, dihitung menggunakan prevalensi pengguna gigi tiruan di Sulawesi Utara sebesar 7,1\% dari total penduduk Kelurahan Batu Kota yang berjumlah 5804 jiwa. Dengan jumlah sampel sebanyak 81 orang menggunakan rumus Slovin. Teknik pengambilan sampel yang digunakan dalam penelitian ini yaitu purposive sampling. Kriteria Inklusi dalam penelitian ini yakni, pengguna GTSL yang bersedia dengan sukarela untuk dijadikan sebagai responden dan bersedia mengisi informed consent, serta bersikap kooperatif selama pengambilan data.

Kriteria eksklusi dalam penelitian ini yakni, Pengguna gigi tiruan sebagian lepasan yang tak memakai cengkram atau retainer.

Pengambilan data dilakukan dengan cara mendatangi tiap rumah responden. Data demografis berupa usia, jenis kelamin, lama penggunaan GTSL, dan jenis GTSL melalui wawancara langsung. Gambaran kerusakan gigi penyangga diperoleh dengan melakukan pemeriksaan langsung dalam rongga mulut, dibantu dengan alat diagnostic. Sebelum melakukan pemeriksaan di rongga mulut, terlebih dahulu subjek mengisi informed consent. Data yang diperoleh, diolah, dianalisis secara manual dan pengajian data dalam bentuk tabel distribusi frekuensi. 
HASIL PENELITIAN

Tabel 1. Distribusi frekuensi responden berdasarkan usia

\begin{tabular}{ccc}
\hline Usia (tahun) & $\mathrm{n}$ & $\%$ \\
\hline $25-35$ & 11 & 13,6 \\
$36-45$ & 16 & 19,8 \\
$46-55$ & 23 & 28,4 \\
$56-65$ & 12 & 14,8 \\
$66-75$ & 13 & 16,0 \\
$76-85$ & 6 & 7,4 \\
\hline Total & 81 & 100 \\
\hline
\end{tabular}

Data pada Tabel 1 menunjukkan bahwa berjumlah 23 orang (28,4\%), 56-65 tahun responden yang berusia 25-35 tahun berjumlah 11 orang (13,6\%), 36-45 tahun berjumlah 16 orang (19,8\%), 46-55 tahun berjumlah 12 orang (14,8\%), 66-75 tahun berjumlah 13 orang (16\%), 76-85 tahun berjumlah 6 orang $(7,4 \%)$.

Tabel 2. Distribusi frekuensi responden berdasarkan jenis kelamin

\begin{tabular}{ccc}
\hline Jenis kelamin & $\mathrm{n}$ & $\%$ \\
\hline Laki - laki & 36 & 44,4 \\
Perempuan & 45 & 55,6 \\
\hline Total & 81 & 100 \\
\hline
\end{tabular}

Tabel 2 menunjukkan bahwa dari 81 laki - laki dan empat puluh lima orang responden yang diteliti terdapat tiga puluh $\quad$ (55,6\%) yang berjenis kelamin perempuan. enam orang $(44,4 \%)$ yang berjenis kelamin

Tabel 3. Distribusi frekuensi responden berdasarkan lama pemakaian GTSL

\begin{tabular}{ccc}
\hline $\begin{array}{c}\text { Lama pemakaian } \\
\text { GTSL } \\
\text { (tahun })\end{array}$ & $\mathrm{n}$ & $\%$ \\
\hline$<1$ & & \\
$1-5$ & 3 & 3,7 \\
$6-10$ & 35 & 30,2 \\
$11-15$ & 25 & 17,3 \\
$16-20$ & 14 & 4,9 \\
\hline Total & 4 & 100 \\
\hline
\end{tabular}

Tabel 3 menunjukkan bahwa responden yang telah menggunakan GTSL selama $<1$ tahun sebanyak tiga orang (3,7\%), 1-5 tahun sebanyak tiga puluh lima orang
(43,2\%), 6-10 tahun sebanyak dua puluh lima orang (30,9\%), 11- 15 tahun sebanyak empat belas orang $(17,3 \%)$ dan $16-20$ tahun sebanyak empat orang (4,9\%).

Tabel 4. Distribusi frekuensi responden berdasarkan jenis GTSL

\begin{tabular}{ccc}
\hline Jenis GTSL & $\mathrm{n}$ & $\%$ \\
\hline Akrilik & 71 & 87,7 \\
Kerangka logam & 10 & 12,3 \\
\hline Total & 81 & 100 \\
\hline
\end{tabular}


Tabel 4 menunjukkan bahwa responden yang munggunakan GTSL berbasis akrilik sebanyak tujuh puluh satu orang $(87,7 \%)$ dan subjek penelitian yang menggunakan GTSL kerangka logam sebanyak sepuluh orang ( $12,3 \%)$.

Tabel 5. Distribusi frekuensi responden berdasarkan kondisi gigi penyangga

\begin{tabular}{ccc}
\hline $\begin{array}{c}\text { Kondisi Gigi } \\
\text { Penyangga }\end{array}$ & $\mathrm{n}$ & $\%$ \\
\hline $\begin{array}{c}\text { Kerusakan pada Gigi } \\
\text { Kerusakan pada } \\
\text { Jaringan Penunjang }\end{array}$ & 24 & 29,6 \\
$\begin{array}{c}\text { Kerusakan pada Gigi \& } \\
\text { Jaringan Penunjang } \\
\text { Sehat }\end{array}$ & 0 & 0 \\
\hline Total & 35 & 43,2 \\
\hline
\end{tabular}

Tabel 5 menunjukkan bahwa responden yang mengalami kerusakan pada gigi sebanyak dua puluh empat orang orang (29,6\%), sedangkan tidak terdapat responden yang mengalami kerusakan pada jaringan penunjang, responden yang mengalami kerusakan pada gigi dan jaringan penunjang sebanyak tiga puluh lima orang $(43,2 \%)$, dan yang tidak mengalami kerusakan sebanyak dua puluh dua orang $(27,2 \%)$.

\section{BAHASAN}

Data hasil penelitian menunjukkan bahwa sebagian besar pengguna GTSL mengalami kerusakan gigi penyangga, kerusakan yang paling banyak terjadi berupa karies pada gigi penyangga. Salah satu kerugian pemakaian GTSL yaitu dapat merusak jaringan mulut yang tersisa. Desain kerangka GTSL yang tidak baik dapat meningkatkan penumpukan sisa makanan pada bagian yang berkontak dengan permukaan gigi asli, yang mengganggu aksi self-cleansing oleh lidah dan pipi selama proses pengunyahan. Terjadinya penumpukan plak akibat terganggunya aksi self-cleansing, berperan dalam perkembangan bakteri dan plak dalam rongga mulut yang antara lain menyebabkan terjadinya karies. Di samping itu juga adanya cengkeram atau retainer yang bersandar pada gigi penyangga memudahkan sisa makanan tersangkut yang berperan pada penumpukan plak. Hal ini selaras dengan dengan penelitian Loho, yang menunjukkan pemakaian GTSL pada pasien RSGM FK UNSRAT memberikan efek berupa karies, trauma langsung, penyakit periodontal dan gigi goyah.,9 Hasil ini juga didukung oleh penelitian Kaltjen dkk yang menunjukkan adanya karies pada gigi penyangga sebesar 6-30\% pertahun dan penelitian yang dilakukan oleh Hicklin dkk., yang menunjukkan bahwa elemen gigi penyangga menghadapi resiko yang lebih besar terhadap karies, yakni sebesar $60 \%$ gigi penyangga mengalami karies sedangkan gigi asli yang berkontak dengan GTSL hanya 24\% yang mengalami karies. ${ }^{3}$

Pada penelitian ini diperoleh hasil bahwa terdapat 54\% pemakai GTSL yang mengalami fraktur pada gigi penyangganya. Menurut penulis hal ini mungkin disebabkan oleh gesekan cengkeram atau retainer yang berlebihan pada gigi penyangga, sehingga rentan terhadap kerusakan. Penyebab lainnya mungkin karena desain gigi tiruan yang kurang tepat sehingga menyebabkan beban yang diterima gigi penyangga terlalu besar atau bisa juga akibat trauma langsung pada pada gigi penyangga yang menyebabkan fraktur. ${ }^{5}$

Mobilitas gigi yang ditemukan pada penelitian ini tidak berdiri sendiri namun disertai dengan gangguan lainnya seperti karies serta kerusakan pada jaringan penunjang gigi yang dijadikan penyangga. 
Salah satu efek negatif dari penggunaan GTSL adalah meningkatnya mobilitas pada gigi penyangga. Penelitian Carlson dkk menunjukkan bahwa GTSL yang telah digunakan selama 4 tahun akan terjadi mobilitas patologis pada $50 \%$ gigi penyangga. ${ }^{3,10}$ Mobilitas pada gigi penyangga dapat terjadi karena oral hygiene yang kurang terjaga, serta akibat adanya gaya-gaya yang bekerja pada GTSL dan berpengaruh juga pada gigi penyangga. Gaya-gaya yang bekerja ini akan menyebabkan jaringan pendukung gigi penyangga menjadi rentan terhadap kerusakan. Seiring dengan berjalannya waktu, maka kemungkinan terjadinya kerusakan pada jaringan periodontal gigi penyangga akan semakin besar.

Hasil penelitian juga menunjukkan bahwa pengguna GTSL yang diteliti hanya mengalami gingivitis saja serta gingivitis yang disertai dengan kerusakan jaringan penunjang lainnya seperti periodontitis, perdarahan,dan mobilitas. Gingivitis dapat terjadi pada jaringan di sekitar gigi penyangga, hal ini bisa dikarenakan desain gigi tiruan yang kurang baik sehingga permukaan basis tidak bersandar pada permukaan gigi asli. Kondisi ini menyebabkan mudahnya terjadi sangkutan sisa makanan dan terjadi penumpukan plak yang dapat menyebabkan gingivitis. Di samping itu gingivitis pada mukosa sekitar gigi penyangga bisa terjadi akibat plak yang terakumulasi pada permukaan basis akrilik yang bersandar pada gigi penyangga. $^{11}$ Karakteristik permukaan basis akrilik yang memiliki pori-pori ireguler dan mikroskopis memudahkan penumpukan sisa makanan dan plak. Jika plak tetap melekat pada gigi selama lebih dari 72 jam, maka akan mengeras dan membentuk karang gigi atau kalkulus yang berdampak pada terjadinya gingivitis. Gingivitis banyak ditemukan pada orang yang menggunakan gigi tiruan yang kurang memerhatikan faktor kebersihan gigi tiruan dan rongga mulutnya. ${ }^{12}$

Pada penelitian ini terdapat juga pengguna GTSL yang mengalami perdarahan di jaringan sekitar gigi penyangga hal ini merupakan salah satu gejala adanya gingivitis. Penyebabnya adalah plak dan kalkulus yang memengaruhi gingiva sehingga dapat terjadi peradangan dan perdarahan. Keparahan gingivitis akan terus berlanjut akibat penumpukan plak sebagai dampak kebersihan rongga mulut yang tidak terpelihara. $^{4,13}$ Hal yang sama juga dinyatakan dalam penelitian Praptinningtyas bahwa sekitar 41,7\% pasien pengguna gigi tiruan mengalami perdarahan pada gingivanya. ${ }^{12}$

Pada penelitian ini ditemukan juga adanya periodontitis pada gigi yang dijadikan penyangga. Periodontitis merupakan kelanjutan dari adanya inflamasi atau peradangan pada gingiva. Gingivitis yang terjadi pada gigi penyangga akibat adanya gaya-gaya yang bekerja pada GTSL serta akibat penumpukan plak pada gigi penyangga dan basis yang bersandar pada gigi penyangga, merupakan awal terjadinya periodontitis pada gigi penyangga. Gingivitis yang dibiarkan dan tidak segera ditangani akan menyebabkan kerusakan pada jaringan penunjang gigi akan terus berlanjut. Proses periodontitis dimulai dari meningkatnya plak pada gigi asli dan gigi tiruan, kemudian menyebabkan inflamasi pada gingiva sampai ke jaringan yang lebih dalam ke arah tulang di bawah gigi (tulang alveolar), sehingga menyebabkan kerusakan yang lebih luas dari jaringan penunjang gigi (jaringan periodontal) yang disebut sebagai penyakit periodontal. Dampak kerusakan yang lebih lanjut berupa mobilitas gigi. Hal ini didukung oleh dengan penelitian yang dilakukan Rasika dkk, yakni dalam 6 bulan setelah pemasangan GTSL maka pengguna sudah mengalami penyakit periodontal. ${ }^{9}$

\section{SIMPULAN}

Berdasarkan hasil penelitian yang dilakukan dapat ditarik kesimpulan sebagai berikut:

1. Kerusakan pada elemen gigi merupakan kerusakan terbanyak dengan jumlah 59 kerusakan. Kerusakan terbanyak berupa karies 
dan karies disertai fraktur masingmasing sebanyak dua puluh sembilan kerusakan (49,15\%), diikuti fraktur sebanyak 1 kerusakan $(1,7 \%)$

2. Kerusakan pada jaringan pendukung gigi didapat sebanyak 72 kerusakan, dengan kerusakan terbanyak berupa gingivitis sebanyak tiga puluh lima kasus (48,6\%), perdarahan sebanyak delapan belas kasus (25\%), periodontitis sebanyak tiga belas kasus $(18,1 \%)$ dan mobilitas sebanyak enam kasus (8,3\%).

\section{SARAN}

1. Pemerintah dalam hal ini Puskesmas Bahu dapat memanfaatkan hasil penelitian ini untuk digunakan dalam penyusunan program pelayanan kesehatan gigi dan mulut terlebih khusus program preventif dan promotif.

2. Bagi masyarakat pengguna GTSL dikelurahan batu kota agar lebih memperhatikan kesehatan dan kebersihan GTSL guna mencegah terjadinya kerusakan pada gigi penyangga sebagai dampak penggunaan GTSL.

DAFTAR PUSTAKA

1. Jalmanggeng. Karies Gigi. [serial online]. 2009 [cited 2010 oct 20] available from URL:

Http://www.JalAryaHtm.com.2008

2. Departemen Kesehatan Republik Indonesia. Laporan Riset Kesehatan Dasar Nasional 2007. Jakarta: Badan Penelitian dan Pengembangan Kesehatan; 2008.

3. Battisttuzzi, Keyser AF, Keltjens, Plasmana. Gigi tiruan sebagai titik tolak pada giagnosa dan perawatan gigi - geligi yang rusak. Ahli bahasa A I Kosasih, A R Koosasih. Editor SusuantiKenjana, Lilian Yuwono. Jakarta : Widya Medika;1196. p. 2628,106,135,261-3,247-8
4. Purba MH. Penanggulangan gigi penyangga pasca pemasangan gigi tiruan sebagian lepasan.[skripsi]FKG:USU. Medan 2000 [diunduh http://repository.usu.ac.id/handle/12345 6789/8123 ]cited 15 Mei 2008

5. Gunadi HA, Margo A, Burhan LK, Suryatenggara F, Setiabudi I. Buku ajar gigi geligi tiruan sebagian lepasan jilid 1. Jakarta: Hipokrates; 2012.

6. Daradjati Sri, Nugraheni Tunjung. Buku Ajar ilmu Konservasi Gigi IV. Yogyakarta. 2004. p. 2-5.

7. Harty F.J dan R Ogston. Kamus kedookteran gigi. Ahli bahasa Narlan Sumawinata.Jakarta: EGC;1995.

8. Tjomson Hamish. Oklusi Edisi 2. Ahli bahasa oleh Suta T dan Juwono Lilian. Jakarta: EGC; 2007. p. 141

9. Pimtip. A clinical survey of removable partial denture after 2 years usage [Thesis]. Australia : University of Sidney. 1979

10.Loho E. Gambaran Efek Pemakaian Gigi Tiruan Sebagian Lepasan pada Pasien di RSGM FK Unsrat[skripsi]. Manado: Universitas Sam Ratulangi. 2014

11.Gunadi HA, Margo A, Burhan LK, Suryatenggara F, Setiabudi I. Buku ajar gigi geligi tiruan sebagian lepasan jilid 2. Jakarta: Hipokrates; 2012. p. 407-412

12.Nila Praptinningtyas. Dampak Pemakaian Gigi Tiruan Mahkota Terhadap Kesehatan Jaringan Gingiva.[skripsi] FKG: UNHAS 2010 [diunduh http://repository.unhas.ac.id/handle/123 456789/1092]cited cited 14 November 2014

13.M. Agsa. Hubungan antara perilaku dengan kejadian gingivitis pada pasien usia 2445 tahun di rumahh sakit gigi dan mulut Halimah Daeng Sikati-Kandea. [skipsi]FKG:UNHAS. Makasar2012[diunduh http://repository.unhas.ac.id/handle/123 456789/2449 ] cited 06 November 2012 